\title{
Response of Wildlife Food Plants to Spring Discing of Mesquite Rangeland in North- west Texas
}

WILLIAM M. WEBB AND FRED S. GUTHERY

\section{Abstract}

The response of wildlife food plants to spring discing of mesquite rangeland was studied in northwest Texas during 1978-80. Discing increased the canopy coverage and frequency of Halls panicum but usually decreased coverage and frequency of other grasses for at least 1 year. Discing promoted western ragweed, amaranth, hairy false-nightshade, scarlet gaura, scarlet globemallow, green carpetweed, and silverleaf nightshade and discouraged yellow woodsorrel, plantain, common broomweed, and Gordon bladderpod.

Soil disturbance by discing creates lower successional communities dominated by forbs (Jackson 1969, Turrentine 1971, Derdeyn 1975, Buckner and Landers 1979). The practice improves food supplies for bobwhites (Colinus virginianus), mourning doves (Zenaida macroura), white-tailed deer (Odocoileus virginianus), and other species. Knowledge of species-specific vegetation response to discing is needed to evaluate the efficiency of the practice. The objective of this study was to document the response of herbaceous wildlife foods to spring discing on rangeland dominated by honey mesquite (Prosopis glandulosa).

\section{Study Area and Methods}

The study was conducted on the Pitchfork Ranch about $25 \mathrm{~km}$ east of Dickens in Dickens and King counties of the Texas Rolling Plains. Climate of the area is warm-temperate with dry winters and summers (Girdner and Richardson 1970). Average annual precipitation is $52 \mathrm{~cm}$, but monthly and annual amounts vary widely. Precipitation usually is highest in May and June with September receiving the next highest amount. The average daily minimum temperature in January, the coldest month, is $-3^{\circ} \mathrm{C}$; the average daily maximum temperature in July and August, the warmest months, is $36^{\circ} \mathrm{C}$. The average growing season is 217 days (4 April to 7 November).

A 30-ha study area was established in March 1978 on a westfacing slope. Soils of the area are Woodward-Quinlan loam with 3 to $15 \%$ slopes in uplands (mixed land range site) and Miles fine sandy loam with 1 to $5 \%$ slopes in lowlands (sandy loam range site).

Mesquite dominated the overstory vegetation at a density of about $440 \mathrm{stems/ha} \mathrm{(B.} \mathrm{Gruver,} \mathrm{unpubl.} \mathrm{data);} \mathrm{some} \mathrm{tasajillo}$ (Opuntia leptocaulis) and netleaf hackberry (Celtis reticulata) occurred in the overstory. Dominant grasses were sideoats grama (Bouteloua curtipendula), hairy grama (B. hirsuta), blue grama (B. gracilis), buffalograss (Buchloe dactyloides), sand dropseed (Sporobolus cryptandrus), fall witchgrass (Leptoloma cognatum), and threeawns (Aristida spp.). Major forbs were yellow woodsorrel (Oxalis dillenii), scarlet gaura (Gaura coccinea), common broomweed (Xanthocephalum dracuncuculoides), and western ragweed (Ambrosia psilostachya).

\footnotetext{
Authors are research associate and associate professor, Department of Range and Wildlife Management, Texas Tech University, Lubbock 79409.

The Noxious Brush and Weed Control Research Program, Department of Range Wildlife Management, Texas Tech University, supported this study.

Manuscript T-9-295, College of Agricultural Sciences, Texas Tech University.

Manuscript received February 6, 1982.
}

The study area was in a 2,484-ha pasture grazed by 212 cows and 15 to 18 bulls during the study.

Spring discing began in March 1978 as part of a habitat management program for bobwhites (Webb 1981). Five strips, $6 \mathrm{~m}$ wide and about $600 \mathrm{~m}$ long, were disced 15 to $25 \mathrm{~cm}$ deep along contours. Each strip was disced again in March 1979 and widened to $9.8 \mathrm{~m}$. Two passes were made with the disc on each strip each year. Prior to the 1979 discing, $4.5 \mathrm{~kg}$ lllinois bundleflower (Desmanthus illinoensis), $4.5 \mathrm{~kg}$ common sunflower (Helianthus annuus), $2.3 \mathrm{~kg}$ tame sunflower, and a small amount of many-flowered pricklepoppy (Argemone polyanthemos) seed were hand broadcast onto each strip. One of the 5 strips was seeded with tame sunflower but by early summer grasshoppers had destroyed all plants.

Vegetation sampling was conducted during July 1978, May and August 1979, and May 1980. Randomly located, permanent 30.5$\mathrm{m}$ lines were established in each of the 5 disced strips and in adjacent nondisced areas. During sampling, a steel tape was stretched between two stakes and held under tension. A $20 \times 50-\mathrm{cm}$ frame was placed at $1-\mathrm{m}$ intervals along the tape and canopy cover of herbaceous plants within the frame was estimated (Daubenmire 1959). Data were transformed $(\sqrt{x+0.5)}$ because of a high frequency of zeros (Steel and Torrie 1960). Both raw and transformed data were analyzed by one-way analysis of variance within each sampling date; vegetation comparisons are made only between disced and undisced areas within sampling dates. Results of statistical tests are reported at the 5\% level of significance.

Botanical nomenclature follows Gould (1975).

\section{Results}

\section{Grass Response}

Spring discing decreasing the canopy coverage and frequency of major grasses on the study area during summer (Table 1). However, coverage and frequency of Halls panicum (Panicum hallii) were significantly greater on the disced strips during both summers. Discing had no effect on coverage of hairy grama in July 1978 but coverage of this species was significantly lower on the disced strips in August 1979.

Data from spring sampling also indicated decreased canopy coverage and frequency values for grasses on the disced strips (Table 2). Coverage of Halls panicum was higher on the disced strips in May 1979, but no difference in coverage was detected between disced and undisced areas in May 1980. Rescuegrass (Bromus unioloides) was the only grass species with higher canopy coverage on disced strips than on undisced areas in May 1980.

Following discing, total canopy coverage of the 11 major grasses was decreased by about 77 and $78 \%$ in July 1978 and August 1979 , respectively, and by about 87 and $74 \%$ in May 1979 and 1980, respectively. Halls panicum provided about $37 \%$ of the grass coverage on the disced strips in July 1978, $21 \%$ in May $1979,53 \%$ in August 1979, and 8\% in May 1980.

Forb Response

Data for the two summer seasons indicated both increases and 
Table 1. Comparisons between mean canopy coverage $(\%)$ and frequency of occurrence $(\%)$ of plants in disced strips and nondisced areas in mesquite rangeland during July 1978 and August $1979(N=15020 \times 50-\mathrm{cm}$ plots per treatment each year).

\begin{tabular}{|c|c|c|c|c|c|c|c|c|}
\hline \multirow[b]{3}{*}{ Species } & \multicolumn{4}{|c|}{1978} & \multicolumn{4}{|c|}{1979} \\
\hline & \multicolumn{2}{|c|}{ Coverage } & \multicolumn{2}{|c|}{ Frequency } & \multicolumn{2}{|c|}{ Coverage } & \multicolumn{2}{|c|}{ Frequency } \\
\hline & Disced & Nondisced & Disced & Nondisced & Disced & Nondisced & Disced & Nondisced \\
\hline \multicolumn{9}{|l|}{ Grasses } \\
\hline Aristida spp. & $2.7 * 1$ & 6.3 & 21.3 & 36.7 & $\operatorname{tr} * 2$ & 1.7 & 1.3 & 26.0 \\
\hline Bouteloua curtipendula & $0.1^{*}$ & 1.4 & 1.3 & 7.3 & $0.4^{*}$ & 1.6 & 7.3 & 8.7 \\
\hline B. gracilis & $0.5^{*}$ & 5.5 & 3.3 & 20.7 & $0.4^{*}$ & 6.9 & 7.3 & 41.3 \\
\hline B. hirsuta & 0.1 & 0.6 & 1.3 & 7.3 & $0.1^{*}$ & 1.2 & 0.1 & 7.3 \\
\hline Bromus unioloides & $0.0^{*}$ & 0.2 & 0.0 & 7.3 & 0.0 & 0.0 & 0.0 & 0.0 \\
\hline Buchloe dactyloides & $0.2^{*}$ & 13.6 & 4.0 & 45.3 & $0.3^{*}$ & 5.4 & 5.3 & 47.3 \\
\hline Erioneuron pilosum & $0.9^{*}$ & 3.9 & 5.3 & 20.7 & $\operatorname{tr}^{*}$ & 0.7 & 0.7 & 13.3 \\
\hline Hordeum pusillum & $\operatorname{tr}^{*}$ & 0.5 & 0.7 & 11.3 & 0.0 & 0.0 & 0.0 & 0.0 \\
\hline Leproloma cognatum & $0.4^{*}$ & 6.3 & 8.0 & 32.0 & $0.8^{*}$ & 2.0 & 10.7 & 22.7 \\
\hline Panicum hallii & $3.7^{*}$ & 0.6 & 57.3 & 12.7 & $2.9^{*}$ & 0.4 & 38.0 & 7.3 \\
\hline Sporobolus cryptandrus & $1.5^{*}$ & 4.8 & 18.7 & 58.7 & $0.6^{*}$ & 5.1 & 16.7 & 62.0 \\
\hline \multicolumn{9}{|l|}{ Forbs } \\
\hline Ambrosia psilostachya & $2.0^{*}$ & 0.8 & 18.0 & 15.3 & $7.2^{*}$ & 0.1 & 30.0 & 5.3 \\
\hline Amaranthus spp. & $3.3^{*}$ & $\operatorname{tr}$ & 16.0 & 0.7 & $2.7^{*}$ & 0.0 & 13.3 & 0.0 \\
\hline Chamaesaracha sordida & 0.5 & 0.0 & 8.0 & 0.0 & $0.6^{*}$ & 0.0 & 4.7 & 0.0 \\
\hline Desmanthus illinoensis & 0.0 & 0.0 & 0.0 & 0.0 & 0.4 & 0.0 & 0.0 & 0.0 \\
\hline Gaura coccinea & 0.9 & 1.9 & 12.7 & 15.3 & 1.1 & 0.6 & 15.3 & 12.0 \\
\hline Helianthus annuus & 0.0 & 0.0 & 0.0 & 0.0 & $4.4^{*}$ & 0.0 & 21.3 & 0.0 \\
\hline Mollugo verticillata & $1.8^{*}$ & 0.1 & 33.3 & 4.0 & $1.8^{*}$ & 0.3 & 14.0 & 4.0 \\
\hline Oxalis dillenii & $0.2^{*}$ & 1.9 & 2.7 & 22.7 & $\mathbf{t r}^{*}$ & 1.4 & 2.7 & 32.0 \\
\hline Plantago spp. & 0.0 & 0.0 & 0.0 & 0.0 & $\mathbf{t r}^{*}$ & 0.6 & 0.7 & 24.7 \\
\hline Solanum elaeagnifolium & 0.7 & 0.5 & 12.0 & 11.3 & $0.8^{*}$ & 0.2 & 16.7 & 5.3 \\
\hline Sphaeralcea coccinea & $1.0^{*}$ & 0.2 & 11.3 & 9.3 & 0.8 & 0.6 & 15.3 & 21.3 \\
\hline Xanthocephalum dracunculoides & 0.0 & tr & 0.0 & 0.7 & $0.3^{*}$ & 8.0 & 12.7 & 89.3 \\
\hline Bare ground & $50.8^{*}$ & 18.3 & 100.0 & 100.0 & $52.9 *$ & 24.5 & 100.0 & 100.0 \\
\hline
\end{tabular}

i* Means significantly different $(P<0.05)$.

${ }^{2} \mathrm{tr}=$ trace $(<0.1 \%)$.

Table 2. Comparisons between mean canopy coverage $(\%)$ and frequency of occurrence $(\%)$ of plants in disced strips and nondisced areas in mesquite rangeland during May 1979 and $1980(N=15020 \times 50-\mathrm{cm}$ plots per treatment each year $)$.

\begin{tabular}{|c|c|c|c|c|c|c|c|c|}
\hline \multirow[b]{3}{*}{ Species } & \multicolumn{4}{|c|}{1979} & \multicolumn{4}{|c|}{1980} \\
\hline & \multicolumn{2}{|c|}{ Coverage } & \multicolumn{2}{|c|}{ Frequency } & \multicolumn{2}{|c|}{ Coverage } & \multicolumn{2}{|c|}{ Frequency } \\
\hline & Disced & Nondisced & Disced & Nondisced & Disced & Nondisced & Disced & Nondisced \\
\hline \multicolumn{9}{|l|}{ Grasses } \\
\hline Aristida spp. & $0.1 * 1$ & 3.3 & 2.0 & 29.3 & $0.1^{*}$ & 3.0 & 2.0 & 30.0 \\
\hline Bouteloua curtipendula & 0.3 & 1.3 & 5.3 & 9.3 & 0.7 & 2.6 & 4.0 & 11.3 \\
\hline B. gracilis & $0.1^{*}$ & 5.3 & 4.7 & 36.0 & $0.6^{*}$ & 6.5 & 4.7 & 32.7 \\
\hline B. hirsuta & $\operatorname{tr} * 2$ & 0.8 & 1.3 & 11.3 & $\operatorname{tr}^{*}$ & 1.8 & 0.7 & 11.3 \\
\hline Bromus unioloides & 0.8 & 1.3 & 22.7 & 21.3 & $2.5^{*}$ & 0.5 & 32.7 & 15.3 \\
\hline Buchloe dactyloides & $0.2^{*}$ & 4.2 & 7.3 & 44.7 & $0.7^{*}$ & 8.5 & 10.7 & 52.0 \\
\hline Erioneuron pllosum & $\operatorname{tr}^{*}$ & 1.2 & 0.7 & 15.3 & $0.1 *$ & 1.3 & 0.7 & 16.0 \\
\hline Hordeum pusillum & $0.6^{*}$ & 1.8 & 8.7 & 28.7 & 1.5 & 1.8 & 22.0 & 24.0 \\
\hline Leptoloma cognatum & $0.2^{*}$ & 1.4 & 6.0 & 20.0 & $0.8^{*}$ & 2.5 & 12.7 & 22.7 \\
\hline Panicum hallii & $0.7^{*}$ & $\operatorname{tr}$ & 18.0 & 0.7 & 0.7 & 0.2 & 11.3 & 6.0 \\
\hline Sporobolus cryptandrus & $0.3^{*}$ & 4.4 & 8.7 & 56.0 & $0.8^{*}$ & 6.1 & 20.7 & 64.0 \\
\hline \multicolumn{9}{|l|}{ Forbs } \\
\hline Ambrosia psilostachya & $3.4^{*}$ & 0.4 & 28.0 & 10.7 & $5.8^{*}$ & $\mathrm{tr}$ & 40.0 & 2.0 \\
\hline Amaranthus spp. & $2.1^{*}$ & 0.0 & 14.0 & 0.0 & $0.6^{*}$ & 0.0 & 18.0 & 0.0 \\
\hline Chamaesaracha sordida & $0.9^{*}$ & 0.0 & 15.3 & 0.0 & $3.9 *$ & 0.5 & 26.0 & 11.3 \\
\hline Desmanthus illinoensis & 0.1 & 0.0 & 1.3 & 0.0 & 0.3 & 0.0 & 1.3 & 0.0 \\
\hline Gaura coccinea & $1.1^{*}$ & 0.0 & 16.7 & 0.0 & $3.0^{*}$ & 0.1 & 28.0 & 4.7 \\
\hline Helianthus annuus & $6.1^{*}$ & 0.0 & 22.7 & 0.0 & $2.2^{*}$ & 0.0 & 14.7 & 0.0 \\
\hline Lesquerella gordonii & $0.1^{*}$ & 1.4 & 2.7 & 48.0 & 0.1 & 0.2 & 3.3 & 7.3 \\
\hline Oxalis dillenii & $0.2^{*}$ & 3.3 & 6.0 & 52.7 & $0.1^{*}$ & 2.7 & 2.7 & 34.0 \\
\hline Plantago spp. & $\operatorname{tr}^{*}$ & 2.4 & 1.3 & 74.0 & $\mathrm{tr}^{*}$ & 0.7 & 0.7 & 26.7 \\
\hline Solanum elaeagnifolium & $1.1^{*}$ & 0.3 & 18.7 & 10.0 & $2.0^{*}$ & 0.8 & 22.0 & 14.7 \\
\hline Sphaeralcea coccinea & $0.8^{*}$ & 1.2 & 12.7 & 29.3 & 2.3 & 1.9 & 24.7 & 30.7 \\
\hline Xanthocephalum dracunculoides & $0.3^{*}$ & 2.3 & 100.0 & 100.0 & $\operatorname{tr}^{*}$ & 0.2 & 1.3 & 9.3 \\
\hline Bare ground & $61.2^{*}$ & 14.1 & 100.0 & 100.0 & $44.0^{*}$ & 23.9 & 100.0 & 100.0 \\
\hline
\end{tabular}

1*Means significantly different $(P<0.05)$.

${ }^{2} \operatorname{tr}=\operatorname{trace}(<0.1 \%)$. 
decreases in canopy coverage and frequency of annual and perennial forbs in response to discing (Table 1). In July 1978, forbs increased by discing were western ragweed, amaranth (Amaranthus spp.), green carpetweed (Mollugo verticillata), and scarlet globemallow (Sphaeralcea coccinea); coverage of yellow woodsorrel decreased significantly.

In August 1979 coverage of hairy false-nightshade (Chamaesaracha sordida), silverleaf nightshade (Solanum elaeagnifolium), western ragweed, amaranth, and green carpetweed was significantly higher on disced strips than on undisced areas (Table 1). The significantly higher coverage of common sunflower on the disced strips undoubtedly was due to the seeding. Although $4.5 \mathrm{~kg}$ of Illinois bundleflower seed were broadcast onto the strips before the 1979 discing, the species responded poorly. Incorporation of seeds too deeply into the soil by the disc may have caused poor emergence or germination. Forbs having significantly decreased canopy coverage in response to discing were yellow woodsorrel, plantain (Plantago sp.), and common broomweed.

Spring data on forb response to discing were similar to those collected during summer. Canopy coverage of western ragweed, amaranth, hairy false-nightshade, scarlet gaura, common sunflower, and silverleaf nightshade was significantly higher on the disced strips during both years while coverage of yellow woodsorrel, plantain, and common broomweed was significantly lower (Table 2). Coverage of Gordon bladderpod (Lesquerella gordonii) was lower on disced than undisced areas during May 1979.

Total canopy coverage of the 13 major forbs was increased about 225 and $170 \%$ during the two summers and 145 and $286 \%$ during the two springs. The three species that provided most of the coverage on undisced areas (yellow woodsorrel, plantain, and common broomweed) were largely replaced on disced areas by western ragweed, amaranth, common sunflower, hairy false-nightshade, scarlet gaura, green carpetweed, and silverleaf nightshade.

\section{Discussion}

The response of forb populations to spring discing on mesquite rangeland generally was gratifying because some species that showed increases are important wildlife foods. Western ragweed is a key species for bobwhites in the Rolling Plains of Texas (Jackson 1969); bobwhites increased on the study area in response to discing and other management (Webb and Guthery 1982). Western ragweed, amaranth, and globemallow can be seasonally important in the diet of scaled quail (Callipepla squamata) (Ault 1981). Scarlet globemallow and western ragweed are eaten by mule deer $(O$. hemionus) in the Rolling Plains of Texas (Sowell 1981), and scarlet globemallow is an important forb for pronghorn antelope (Antilocapra americana) in this region (Koerth et al. 1983).

In some cases, however, the discing decreased the coverage and frequency of important forbs, including plantain and bladderpod; these cool-season forbs can be important to scaled quail (Ault 1981) and mule deer (Sowell 1981). Discing earlier in the dormant season than March or alternating strips that are disced in successive years could mitigate the negative impact on these forbs.

Although changes in species composition that resulted from the discing were largely beneficial to game animals, forb production and density on the disced strips appeared undesirably low. Coverage of bare ground averaged 40 to $60 \%$ on the strips (Tables 1, 2). Forb production might be improved by control of mesquite adjacent to the disced areas; the lateral roots of this species are highly competitive for surface soil moisture that could be used by herbaceous vegetation (Sosebee 1980). Also, fertilization can stimulate forb production on disced areas (Moore 1972, Derdeyn 1975). Soil treatments that improve precipitation infiltration rates, such as listing or furrow-dyking, might also be beneficial. Whereas the above practices likely would improve forb production, they would add to the basic cost of discing, which is about $\$ 25 /$ ha.

\section{Literature Cited}

Ault, S.C. 1981. Food selection by scaled quail in northwest Texas. M.S. Thesis. Texas Tech Univ., Lubbock.

Buckner, J.L., and J.L. Landers. 1979. Fire and disking effects on herbaceous food plants and seed supplies. J. Wildl. Manage. 43:807-811.

Daubenmire, R. 1959. A canopy-coverage method of vegetation analysis. Northwest Sci. 33:43-65.

Derdeyn, C.H. 1975. Manipulating central Oklahoma rangeland vegetation for bobwhite quail. M.S. Thesis. Oklahoma State Univ., Stillwater.

Girdner, C.L., Jr., and W.E. Richardson. 1970. Soil survey of Dickens County, Texas. USDA-Soil Conserv. Serv. Washington, D.C.

Gould, F.W. 1975. Texas plants-a checklist and ecological summary. Texas Agr. Exp. Sta. Misc. Pub. 585. Rev.

Jackson, A.S. 1969. Quail management handbook for west Texas Rolling Plains. Texas Parks and Wildl. Dep. Bull. 48.

Koerth, B.H., L.J. Krysl, B.F. Sowell, and F.C. Bryant. 1983. Estimating seasonal diet quality of pronghorn antelope from fecal analysis. J. Range Manage. 37:(In press).

Moore, W.H. 1972. Managing bobwhites in the cutover pinelands of south Florida. p. 56-65 In: J.A. Morrison and J.C. Lewis, eds. Proc. First Nat. Bobwhite Quail Symp. Oklahoma State Unjv., Stillwater.

Steel, R.G.D., and J.H. Torrie. 1960. Principles and procedures of statistics. McGraw-Hill Book Co., Inc., New York.

Sosebee, R.E. 1980. Water-a precious commodity to everyone. p. 9-11. In: R.W. Sosebee and F.S. Guthery, eds. Noxious Brush and Weed Control Res. Highlights. Vol. 11. Dep. of Range and WildI. Manage., Texas Tech Univ., Lubbock.

Sowell, B.F., 1981. Nutritional quality of mule deer diets in the Texas Panhandle. M.S. Thesis. Texas Tech Univ., Lubbock.

Turrentine, J.M. 1971. The ecology of bobwhite quail in aerially sprayed sand shinnery oak habitat. M.S. Thesis. Texas Tech Univ., Lubbock.

Webb, W.M. 1981. Response of bobwhites to habitat management in the Rolling Plains of Texas. M.S. Thesis. Texas Tech Univ., Lubbock.

Webb, W.M., and F.S. Guthery. 1982. Response of bobwhite to habitat management in northwest Texas. Wildl. Soc. Bull. 10:142-146. 